\title{
The Preparation and Testing Of Instruments Research on Factors Affecting the Productivity of Household Farmer
}

\author{
Allen A. Ch. Manongko \\ Faculty of Economics, Manado State University, Indonesia
}

\begin{abstract}
This research is for: 1) Develop and explain research instruments on factors that affecting the productivity of household's farmers; and 2) testing of validity and reliability on factors that affecting the productivity of household's farmers. Research samples in total of 381 farmer's household in Minahasa district, with data collecting technique through questionnaire using Likert scale. Instruments testing is done by two ways, that are: first, testing of validity and reliability an instrument; second, testing of validity and reliability construct. With a test using a SPSS program version 16 and Excel Application. The variables in this research are: farmer's perceptions; farmer's conditions; farmer's attitude; farmer's behaviour; consumptive behaviour; productivity of household's farmers; which consists from 35 indicators and 71 items. The result and conclusion of the study: 1) The results of testing validity and reliability instrument with a sig.t test (valid) and Cronbach's alpha (reliable) showing validity (sig.t <0.05) and reliability (Cronbach's alpha > 0.6) instruments. By this we can conclude that all research instruments have validity/accuracy and reliability/conformance in measuring productivity of household's farmers in Minahasa District. 2). The results of testing validity construct show that value of convergent validity $1^{\text {st }}$ and $2^{\text {nd }}$ has a value loading factor $>0.05$ and discriminant validity has a value root of AVE > correlation between latent, and the results of testing reliability construct obtainable value composite reliability $(C R)$ from all latent construct more than 0.7 .
\end{abstract}

Keyword: Instrument, Validity, Reliability, Productivity of household's farmers

\section{Introduction}

The tendency of agriculture's development in Indonesia is slow and even weakened. This is proved from the level of productivity and earnings of farmer's household that is low. From the existing search, the mentioned tendency is leading to less integrity that integrated between farmers, stakeholder, and government. Productivity problem is related to some of the inputs that's processed to produce a number of outputs. Psychologically, the productivity here is interpreted into a mental attitude for quality of life that is better than previous condition. Reflection from quality of life especially farmer's household is illustrated from the ability that is owned by the members of the household to manage and harness the economic resources like fields, labors, business funding, and technology in an effective and efficient way.

The fundamental problem in addition to the needs of farmer's household, the fundamental issue is how to manage and use natural resources in productive agriculture. Barnum and Squire (1979); Singh, et.al. (1986); Sawit (1994) argues that efforts to improve the productivity of farm households can be done with optimization households through: a) the production process that is generated from the farmer's household, b) allocation of the results of such production for own consumption and sale, c) purchase of commodities not produced, d) the allocation of labour. Such efforts, can also be synchronized with the behaviour of living of every household, as stated by Notoatmodjo (2007) by indicating the elements of attitudes, knowledge, and skills in the act, which is linearly positive attitude can change the mindset in the form of the knowledge of the individual, and alteration of existing knowledge can be drawn from the individual skills. Change someone's behaviour, can be done through learning and environmental factors.

In relation to this study, the factors that affect the productivity of farmer's household need to be clearly identified and structured. It is necessary for the preparation and accurate testing. Factors that have been identified (according to theoretical and empirical studies) can be used as an instrument of research. The instrument is a tool used to measure a variable (indicator or manifest). Suryabrata (2008) says that the instruments of collecting data as a tool to record quantitatively about the state and activity of psychological attributes either cognitive or non-cognitive in form of a question or statement.

The quality of research identified by the ability of the instrument being built or developed has an element of reliability and validity. Mueller (1986) found the quality of the instrument is determined by two main criteria, namely the validity and reliability. Thus, the nature of the instrument is a measuring instrument that has the quality of a good validity and reliability and are used to collect the data in a study. Instruments serves to uncover and transform facts into the data, if the instrument used has reliable quality (valid) and valid (reliable), the data obtained will be appropriate or describe the actual state. Conversely, if the quality of the instruments used are not reliable and valid, then the data can be considered inconsistent with the facts on the ground, so that 
The Preparation and Testing Of Instruments Research on Factors Affecting the Productivity of ..

its continuation will result in a wrong conclusion. By this, Sevilla (1988) revealed that a good instrument is an instrument that has criteria: validity; reliability; sensitivity; objectivity; and feasibility. In studies using quantitative methods, the quality of data collection is determined by the quality of the instrument or data collection tool used. A research instrument is said to be qualified and accountable if proven validity and reliability. Testing the validity and reliability of the instrument, must be adapted to the shape of the instruments to be used in research. In this study, the instruments are prepared and tested in accordance with the theory and empirical studies, as well as the facts on the ground. As for the variables to be examined in this study are: the perception of farmers; conditions of farmers; farmer's attitude; productive behaviour; consumptive Behaviour; and productivity of farmer's household. Based on the above, the purpose of this study was to: 1) develop and explain the instruments of research on factors that affect the productivity of farm households; and 2) test the validity and reliability of the factors that affect the productivity of farmer's household.

\section{Preparation of Instrument Procedures}

\section{Literature Review}

A high-quality research, the most important thing and must-have is the instrument. That is because the validity or the validity of the data obtained will be largely determined by the quality of the instruments used, in addition to data collection procedures were adopted. Instruments serves disclose facts into data, so that if the instrument used of sufficient quality in the sense of valid and reliable, the data obtained will be in accordance with the actual facts or circumstances on the ground. Medium if the quality of the instruments used are not good in the sense of having the validity and reliability is low, the data obtained is not valid or not in accordance with the facts on the ground, which can lead to a wrong conclusion. Some of the steps that must be done to set up the instrument so that the instrument unfits for use, pointed out by Thorndike (1982) include: (a) defining a region or attributes latent to be measured (b) determine who will use or who the respondents, (c) specify contents, cover any topic and Djaali According Muljono (2008), measures the development of the instrument are as follows: (1) formulate a construct based on a synthesis of the theories that were examined, (2) from the construct developed dimensions and indicators of the variables to be measured, (3) make a grating instrument in the form of specification table containing the dimensions, indicators, item number and quantity grains, (4) determining the amount or parameter within a range of continuum, (5) writing grains instrument in the form of a statement or question, (6) performs a validation process, (7) to validate the theoretical, (8) revised based on the results of the panel, (9) conducted a doubling instrument for testing, (10) testing in the field which is the empirical validation, (11) test the empirical validity by using the criteria of both internal and external, (12) based on criteria derived conclusions about the validity of an item or the instrument, (13) based on the results of the analysis of the particle, the particles that is invalid are to be removed or repaired, valid particles are reassembled, (14) calculate the reliability coefficient, and (15) the reassembly of the grain of a valid instrument to be used as an instrument.

In this study, steps are designed formulated as follows: 1) establish the productivity of farming households as variables that will be developed instrument; 2) To formulate the conceptual and operational definitions of variables as a psychological response in the form of a person's feelings or emotions; 3) preparing grains have a question or a statement of each variable that exists as the assessment instrument based on the Likert scale; 4) validate theoretically and empirically as judges for the selection of grains have a question or a statement; 5) carry out trials instruments; 6) analysing the grains with the procedure validity and reliability of the instrument; 7) to test the construct appropriate confirmatory factor analysis; 8) analyse the construct validity and reliability; 9) revise and establish a complete instrument.

\section{Productivity of household's farmers}

Philosophically, productivity implies a view of life and mental attitude always endeavour transform and improve the quality of life (Sinungan, 2003). The state of today should be better than yesterday, and tomorrow's quality of life should be better than today. View of life and mental attitude so would encourage people not to be easily satisfied, but continue to develop themselves and improve employability. Operationally, productivity is a comparison between the results achieved (outputs) with the overall resources (inputs) used per unit of time. Krech, et al (1963) found the productivity implies a comparison between the results achieved with the overall resources used. Related to the productivity of businesses farmer households, improving productivity is not only measured by the management of the farm but take into account other aspects that affect productivity itself as the management efforts of farmers, institutional support as well as aspects of the farmers themselves concerning psychological factors of farmers.

Psychological factors of household farmers are part of the mental attitude of farmers to improve the quality of social and economic life of the farmer's household. As individuals in the households of farmers associated with the level of education, farming experience, and as a socioeconomic associated with a land area of business, working capital, and labour. This is similar to Soebijanto (1999), in his research states that there is a real connection between formal education, farming experience, extensive exploitation of land, capital, labour, 
The Preparation and Testing Of Instruments Research on Factors Affecting the Productivity of ..

and the application of technology, the farm productivity. Thus, an understanding of productivity should be regarded as psychologic and economy, as well as the system. Simultaneously, increased productivity processed from mental attitude and outlook on life farming household, which is always thinking and trying to change lifestyle to improve the quality of life, by generating the resources effectively and efficiently, in an effort to achieve goals that are relevant and integrated.

In this study, the productivity of household's farmers can be evaluated from four aspects: land use, use of technology, workforce management, and capital management. Rate land productivity associated with the technology used, which requires the knowledge to know the type of soil, its spread, and the inputs needed to overcome and improve productivity, as well as its response to the application of technology.

\section{Behavioural Economics}

The framework of macro, household is classified as one of the economic actors, in addition to other actors who comprise the manufacturers, governments, financial institutions, and other countries. In operational economic activity, households develop economically rational behaviour, namely: attempt to maximize revenues in productive activities, and streamline expenditure in consumptive activities to maximize his utility. To study the behaviour of domestic economic activity, can be done in microeconomics. In the consumption activities, households are assumed to act rationally, in the sense of always working to get pleasure and satisfaction (utility) of the maximum.

\section{Farmer's Attitude}

Attitude is a determinant of behaviour, which is related to the perception of personality and motivation. Attitude is a state of mental attitude, studied and organized according to experience, and that led to a special influence on a person's reaction to people, objects, and situations with whom he associated. Changes in attitude depends on the effort to change his feelings or those beliefs. Winardi (2004), humans have an attitude that consists of a wide range of affective and cognitive components. Affective which is a component of emotional or feeling. The cognitive component comprises an attitude of perceptions, opinions and beliefs. Sarwono (2002) reveals that attitudes consist of various components: cognitive, affective and conative. The cognitive component comprises an attitude of perceptions, opinions and beliefs. Affective which is a component of emotional or feeling. While conative aspects, related with the process to behave or act on an object.

\section{Farmer's conditions}

The condition of farmers is the prevailing state of dynamic physical and non-physical experienced by farmer's household. Some aspects related to the condition of the farmers include: age; extensive farming; social status; education; and farming experience.

\section{Farmer's perception}

Perception of farmers is a view over the abilities possessed by farmer's household in an effort to cultivate and improve farming. Matters related to the perception of farmers include: the availability of capital; the availability of facilities and infrastructure; natural environment / physical; market access; price; family; social participation; innovation.

\section{Methods and Implementation Research}

\section{Method}

The method used in this study is a survey. Study survey research approach is one that is generally used for data collection and widely. While data collection techniques used in this study using a questionnaire instrument. Questionnaire is a technique of data collection is done by giving a set of questions or a written statement to the respondent to be answered (Sugiyono, 2010). Variables examined in this study is the productivity of farming households in Minahasa district. Implementation of the research carried out for three months, to be located in three districts (Langowan West, Tompaso, and Kawangkoan West) in Minahasa.

\section{Population and Sample}

The population in this study are all farmer's household in Minahasa, while the sample is done in stages by using the technique of non-probability sampling method stratified random sampling and purposive sampling, and refers to farming households with agricultural horticultural product specifications. Number of samples obtained by using the formula of Daniel and Terrel (1989). Total population of 39,787 people, the sample obtained is 381 farmer's household (RTP).

\section{Research Instrument}

Steps drafting research instruments are as follows: 1) define a variable that will develop instrument; 2) To formulate the conceptual and operational definitions of variables; 3) preparing particles have a question or a 
The Preparation and Testing Of Instruments Research on Factors Affecting the Productivity of ..

statement that each variable exists as assessment instrument based on the Likert scale; 4) validate theoretically and empirically as judges for the selection of grains have a question or a statement; 5) carry out trials instruments; 6) analysing the grains with the procedure validity and reliability of the instrument; 7) to test the construct appropriate confirmatory factor analysis; 8) analyse the construct validity and reliability; 9) revise and establish a complete instrument.

\section{Instrument Development}

Instruments developed every variable of indicator development was based on the results of theoretical study, frame of mind, and operational definitions are considered adequate according to the context of this research. The description is as follows:

1) Farmer's Perception $\left(\mathrm{X}_{1}\right)$. Indicators, namely: availability of capital; The availability of facilities and infrastructure; The natural environment / physical; Market access; Price; Family; Social participation; Innovation.

2) The condition of Farmers $\left(\mathrm{X}_{2}\right)$. Indicators, namely: age; Land area; Social status; Education; Experience.

3) Farmer's Attitude $\left(\mathrm{Y}_{1}\right)$. Indicators, namely: Cognitive; Affective; Conative.

4) Productive Behaviour $\left(\mathrm{Y}_{2}\right)$. Indicators, namely: Variety of productive activity; Expended time for productive activities; Resource use; Investment and saving; Economies of scale; The results obtained; Productive motive; The influence of socio-economic environment.

5) Consumer's Behaviour $\left(\mathrm{Y}_{3}\right)$. Indicators, namely: Composition fulfilment in accordance with the level of urgency; Variety of goods and services consumed; The process of acquisition of goods and services; Economies of scale; The amount of the expenditure; Motif consumptive; The influence of socio-economic environment.

6) Productivity of Farmer's Household $\left(\mathrm{Y}_{4}\right)$. Indicators, namely: Land use; Workforce management; Use of technology; Capital management.

Measurement instrument from all six of the above variables using a Likert scale with five alternative answers, namely: Strongly Agree (SA-5); Agree (A-4); Neutral (N-3); Disagree (D-2); and Strongly Disagree (SD-1).

\section{Testing Validity and Reliability \\ Instrument Validity}

Validity indicates the extent to which the gauges to measure what is being measured. According to Sugiyono (2010), the results are valid if there are similarities between the data collected by the data actually happened in the object studied. Valid or not an item instrument can be seen by comparing the Pearson product moment correlation index with a significance level of $5 \%$ with a critical value, where $\mathbf{r}_{\mathbf{x y}}$ can use the formula (Sugiyono, 2010). The instrument is valid if the significant value $\mathrm{t}(\mathrm{sig} \mathrm{t})$ of Pearson correlation results less than 0.05 .

\section{Instrument Reliability}

Sugiyono (2007) states that a reliable instrument is an instrument which, when used several times to measure the same object, will generate the same data. Reliability is an index indicating the extent to which a measuring device is trusted or reliable. Cronbach alpha for test use, the instrument is declared reliable if the Cronbach alpha values $>0.6$.

\section{Testing Validity and Reliability (construct) Construct Validity}

To test the validity of the SEM is used by construct validity or also called factorial validity, using the approach of multi trait-multi-method, for example by testing the convergent and discriminant validity (Campbell and Fiske, 1959). Convergent validity test can be seen from the loading factor for each indicator constructs. Loading factor is said to be valid when the item is positive and greater 0.5 . While the discriminant validity of each variable in measuring the latent variable indicated by the roots of Average Variance Extracted (AVE). A variable is said to have discriminant validity if the root of AVE> correlation between latent constructs (Fornell and Larcker, 1981).

\section{Construct Reliability}

Construct reliability testing conducted using measures of reliability construct or use the item number of the overall variance explained by latent constructs or so-called discriminant reliability. Criteria for testing if the value of composite reliability (CR) or greater reliability rho 0.7 (Cut off) it can be stated constructs have been reliable. 
The Preparation and Testing Of Instruments Research on Factors Affecting the Productivity of ..

Characteristics of Respondents

\section{Results And Discussion}

\begin{tabular}{|c|c|c|}
\hline \multicolumn{2}{|l|}{ Characteristics } & $\mathbf{F}$ \\
\hline \multirow[t]{5}{*}{ Age } & $\leq 30$ & 11 \\
\hline & $31-40$ & 114 \\
\hline & $41-50$ & 147 \\
\hline & $51-60$ & 102 \\
\hline & $\geq 60$ & 7 \\
\hline \multirow[t]{5}{*}{ Education } & Elementary & 148 \\
\hline & Middle & 106 \\
\hline & High & 117 \\
\hline & Diploma & 6 \\
\hline & S1 & 4 \\
\hline Land ownership & $0: 01$ to $0: 49$ & 237 \\
\hline \multirow[t]{3}{*}{ (in hectare) } & $0.5-1.0$ & 120 \\
\hline & $>1.0$ & 13 \\
\hline & None & 11 \\
\hline Dependant Family & $<2$ & 48 \\
\hline \multirow[t]{2}{*}{ (people) } & $2-3$ & 260 \\
\hline & $4-5$ & 72 \\
\hline Farm income & $<1$ & 158 \\
\hline \multirow[t]{5}{*}{ (million) } & $1-1.5$ & 117 \\
\hline & $1.5-2$ & 52 \\
\hline & $2-3$ & 32 \\
\hline & $3-4$ & 15 \\
\hline & $>4$ & 7 \\
\hline
\end{tabular}

Source: Processed

The table on the right is associated with the demographic characteristics of the respondents and the background of the respondents. Things that are described are: the characteristics by age; education; land ownership; the number of dependents; farm income.

\section{Preparation of Research Instruments}

Research instruments, arranged as the table below:

\begin{tabular}{|c|c|c|c|}
\hline Variable/Indicator/Scale & Items & Variable/Indicator/Scale & Items \\
\hline \multicolumn{4}{|l|}{ Independent Variable (Likert Scale) } \\
\hline \multicolumn{2}{|l|}{ Farmer's Perception $\left(X_{I}\right)$} & \multicolumn{2}{|l|}{ Farmer's Condition $\left(\mathrm{X}_{2}\right)$} \\
\hline 1. Funds Availability $\left(\mathrm{X}_{1.1}\right)$ & 1,2 & 1. Age $\left(\mathrm{X}_{2.1}\right)$ & 17 \\
\hline 2. Tools Availability $\left(\mathrm{X}_{1.2}\right)$ & 3,4 & 2. Farm Size $\left(\mathrm{X}_{2.2}\right)$ & 18,19 \\
\hline 3. Natural/Physical Environment $\left(\mathrm{X}_{1.3}\right)$ & 5,6 & 3. Social Status $\left(\mathrm{X}_{2.3}\right)$ & 20,21 \\
\hline 4. Market $\left(\mathrm{X}_{1.4}\right)$ & 7,8 & 4. Education $\left(\mathrm{X}_{2.4}\right)$ & 22,23 \\
\hline 5. Price $\left(X_{1.5}\right)$ & 9,10 & 5. Experience $\left(\mathrm{X}_{2.5}\right)$ & 24,25 \\
\hline 6. Family $\left(\mathrm{X}_{1.6}\right)$ & 11,12 & & \\
\hline 7. Social Participation $\left(\mathrm{X}_{1.7}\right)$ & 13,14 & & \\
\hline 8. Innovation $\left(\mathrm{X}_{1.8}\right)$ & 15,16 & & \\
\hline \multicolumn{4}{|l|}{ Dependent Variable (Likert Scale) } \\
\hline \multirow{4}{*}{$\begin{array}{cc}\text { Farmer's Attitude }\left(\boldsymbol{Y}_{\boldsymbol{I}}\right) \\
\text { 1. } \\
\text { 2. } & \text { Affective Aspects }\left(\mathrm{Y}_{1.1}\right) \\
\text { 3. } & \text { Conative Aspects }\left(\mathrm{Y}_{1.3}\right) \\
\end{array}$} & & \multicolumn{2}{|l|}{ Consumer's Behaviour $\left(Y_{3}\right)$} \\
\hline & 26,27 & 1. Composition of the fulfilment of the & 49,50 \\
\hline & 28,29 & appropriate level of urgency $\left(\mathrm{Y}_{3.1}\right)$ & \\
\hline & 30,31 & 2. Variety of goods/services consumed $\left(\mathrm{Y}_{3.2}\right)$ & 51,52 \\
\hline \multicolumn{2}{|l|}{ Productive Behaviour $\left(\mathrm{Y}_{2}\right)$} & 3. The process of acquisition of goods and & 53,54 \\
\hline \multirow{4}{*}{$\begin{array}{l}\text { 1. Variety productive activities of formal, informal, } \\
\text { subsystems }\left(\mathbf{Y}_{2.1}\right) \\
\text { 2. Expended time productive activities }\left(\mathbf{Y}_{\mathbf{2 . 2}}\right) \\
\text { 3. Utilization of resources for productive activities } \\
\left(\mathbf{Y}_{2.3}\right) \\
\text { 4. Investment activity of saving }\left(\mathbf{Y}_{\mathbf{2 . 4}}\right)\end{array}$} & 32,33 & $\begin{array}{l}\text { services consumed }\left(\mathrm{Y}_{3.3}\right) \\
\text { 4. The application of economic principles to }\end{array}$ & \\
\hline & 34,35 & consume $\left(\mathrm{Y}_{3.4}\right)$ & \\
\hline & \multirow[t]{2}{*}{36,37} & $\begin{array}{l}\text { 5. The amount of consumption expenditures } \\
\left(\mathrm{Y}_{3.5}\right)\end{array}$ & 56,57 \\
\hline & & 6. Consumption motive $\left(\mathrm{Y}_{3.6}\right)$ & 58,59 \\
\hline \multirow{6}{*}{$\begin{array}{l}\text { 5. The application of economic principles in } \\
\text { productive activities }\left(\mathbf{Y}_{2.5}\right) \\
\text { 6. Results obtained from productive activities }\left(\mathbf{Y}_{\mathbf{2 . 6}}\right) \\
\text { 7. Motif productive activities }\left(\mathbf{Y}_{2.7}\right) \\
\text { 8. Influence of socioeconomic environ-ment on } \\
\text { productive activities }\left(\mathbf{Y}_{2.8}\right)\end{array}$} & \multirow[t]{2}{*}{$\begin{array}{l}38,39,40 \\
41\end{array}$} & $\begin{array}{l}\text { 7. The influence of socio-economic environ- } \\
\text { ment on consumption activities }\left(\mathrm{Y}_{3,7}\right)\end{array}$ & $\begin{array}{l}60,61 \\
62,63\end{array}$ \\
\hline & & The productivity of farm households $\left(Y_{4}\right)$ & \\
\hline & $42,43,44$ & 1. Land Use $\left(\mathrm{Y}_{4.1}\right)$ & 64,65 \\
\hline & & 2. Labour management $\left(\mathrm{Y}_{4.2}\right)$ & 66,67 \\
\hline & 45,46 & 3. Utilization Technology $\left(\mathrm{Y}_{4.3}\right)$ & 68,69 \\
\hline & 47,48 & 4. Fund Management $\left(\mathrm{Y}_{4.4}\right)$ & 70,71 \\
\hline
\end{tabular}

Sources: processed 
The Preparation and Testing Of Instruments Research on Factors Affecting the Productivity of ..

Research Instruments (questionnaire) and respondents result below:

\begin{tabular}{|c|c|c|c|c|c|}
\hline \multirow[t]{3}{*}{ VARIABLE and STATEMENTS ITEMS } & \multicolumn{5}{|c|}{ ANSWERS } \\
\hline & SS & $\mathbf{S}$ & $\mathbf{N}$ & TS & STS \\
\hline & 5 & 4 & 3 & 2 & $\mathbf{1}$ \\
\hline \multicolumn{6}{|l|}{ Variable: Farmer's Perception (X1) } \\
\hline $\begin{array}{l}\text { 1. According to the farmer, the availability of capital is an important factor for the } \\
\text { farmer households in the attempt. }\end{array}$ & 127 & 192 & 25 & 37 & 0 \\
\hline $\begin{array}{l}\text { Institutions credit assistance (cooperatives / banks) are always helpful and ensure } \\
\text { the availability of funds for your household in the attempt. }\end{array}$ & 92 & 108 & 116 & 64 & 1 \\
\hline $\begin{array}{l}\text { The availability of adequate means of agricultural production, is helping a brother } \\
\text { in accelerating the work. }\end{array}$ & 68 & 235 & 56 & 22 & 0 \\
\hline $\begin{array}{l}\text { 4. Infrastructure (roads, irrigation, warehouses, etc.) that are available at this time has } \\
\text { been sufficient to support the sustainability of farming. }\end{array}$ & 42 & 146 & 173 & 20 & 0 \\
\hline How often do you complain to the structure of your land? & 48 & 137 & 144 & 47 & 5 \\
\hline $\begin{array}{l}\text { 6. How can you anticipate as natural disasters or climate change and extreme } \\
\text { weather? }\end{array}$ & 48 & 115 & 168 & 47 & 3 \\
\hline Near markets allows you to sell their harvest directly. & 37 & 205 & 130 & 9 & 0 \\
\hline $\begin{array}{ll}\text { 8. How often do you sell yields directly without using intermediaries (collectors or } \\
\text { retailers)? }\end{array}$ & 31 & 149 & 189 & 12 & 0 \\
\hline Whenever the harvest arrives, you always get a suitable price. & 39 & 133 & 201 & 8 & 0 \\
\hline Prices fluctuate very influential to you in business. & 108 & 225 & 36 & 12 & 0 \\
\hline $\begin{array}{l}\text { 11. Each member of your family always provide value and benefits to smoothness of } \\
\text { household's business. }\end{array}$ & 166 & 183 & 14 & 18 & 0 \\
\hline 12. In farming, family members were always helpful. & 63 & 253 & 50 & 15 & 0 \\
\hline 13. How often do your household participate in community activities? & 40 & 262 & 54 & 25 & 0 \\
\hline $\begin{array}{l}\text { 14. How often do social groups in the villages / wards provide assistance for the } \\
\text { development of your household. }\end{array}$ & 28 & 160 & 132 & 58 & 3 \\
\hline 15. You always make innovations in promoting RT. & 56 & 147 & 134 & 44 & 0 \\
\hline $\begin{array}{l}\text { 16. Innovative capability (positive changes) are very helpful for any individual or } \\
\text { group to adjust and improve their lives. Do you agree with this opinion? }\end{array}$ & 135 & 199 & 14 & 33 & 0 \\
\hline \multicolumn{6}{|l|}{ Variable: Farmer's Condition (X2) } \\
\hline $\begin{array}{l}\text { 17. As age increases, it will affect the productivity of a person. Do you agree with that } \\
\text { statement? }\end{array}$ & 65 & 184 & 123 & 9 & 0 \\
\hline $\begin{array}{l}\text { 18. Status of Land ownership is an important factor for the sustainability of farmer's } \\
\text { household cultivate farming. }\end{array}$ & 111 & 239 & 24 & 7 & 0 \\
\hline $\begin{array}{l}\text { 19. Do you agree that an adequate farming land area, will guarantee more or less } \\
\text { yields? }\end{array}$ & 54 & 165 & 142 & 20 & 0 \\
\hline 20. You are always trying hard to be honoured in your living environment. & 93 & 248 & 33 & 7 & 0 \\
\hline $\begin{array}{l}\text { 21. With the ownership of land, big houses, level of education and high income, is } \\
\text { believed to have a high social status in society. Do you agree with that statement? }\end{array}$ & 54 & 151 & 155 & 20 & 1 \\
\hline $\begin{array}{l}\text { 22. Do you agree that the higher the education level, the greater the household's ability } \\
\text { to increase its productivity? }\end{array}$ & 39 & 109 & 201 & 32 & 0 \\
\hline $\begin{array}{l}\text { 23. With the education that you have, you are always being entrusted to solve the } \\
\text { problems that exist in society. }\end{array}$ & 34 & 127 & 199 & 21 & 0 \\
\hline $\begin{array}{l}\text { 24. You have always felt that the experience of farming has been very supportive for } \\
\text { my household to become more productive. }\end{array}$ & 104 & 214 & 55 & 8 & 0 \\
\hline $\begin{array}{l}\text { 25. How successful is your farming experience that it can adapt to the technological } \\
\text { developments in the field of agriculture? }\end{array}$ & 84 & 166 & 122 & 9 & 0 \\
\hline \multicolumn{6}{|l|}{ Variable: Farmer's Attitude (Y1) } \\
\hline $\begin{array}{l}\text { 26. You always have ideas or creative new ideas to manage and using resources in the } \\
\text { household economy }\end{array}$ & 25 & 166 & 178 & 12 & 0 \\
\hline $\begin{array}{l}\text { 27. How often do you make a change to improve the productivity of farmer's } \\
\text { household? }\end{array}$ & 18 & 87 & 204 & 72 & 0 \\
\hline $\begin{array}{l}\text { 28. The mental attitude to become a farmer is the primary motivation for household to } \\
\text { fulfil life necessities. }\end{array}$ & 76 & 275 & 30 & 0 & 0 \\
\hline I will always be a farmer, since farming is the source of my household's life. & 103 & 194 & 81 & 3 & 0 \\
\hline 30. You always make a simple plan that suits my ability & 29 & 249 & 103 & 0 & 0 \\
\hline $\begin{array}{l}\text { 31. In running the farm, I always make a plan about all costs (seed, fertilizer, and } \\
\text { other), before doing the activity. }\end{array}$ & 59 & 281 & 41 & 0 & 0 \\
\hline \multicolumn{6}{|l|}{ Variable: Productive Behaviour (Y2) } \\
\hline $\begin{array}{l}\text { 32. In funding all their household needs, apart from obtaining from farming, I gained } \\
\text { an extra from other businesses. }\end{array}$ & 62 & 123 & 107 & 88 & 1 \\
\hline $\begin{array}{l}\text { 33. You do not feel guilty about doing other work outside the farm, although it may } \\
\text { reduce the income / working area of another person. }\end{array}$ & 26 & 52 & 126 & 158 & 19 \\
\hline 34. How often do you spend time working in the garden / paddy field? & 80 & 227 & 56 & 18 & 0 \\
\hline $\begin{array}{l}\text { 35. I always oblige all family members to devote his time working in the farming and } \\
\text { non-farming every day. }\end{array}$ & 38 & 146 & 153 & 44 & 0 \\
\hline $\begin{array}{l}\text { 36. If you have a buffalo / cow or production facilities that can be rented out, you keep } \\
\text { trying to rent it out to those in need (rental fee). }\end{array}$ & 41 & 249 & 73 & 17 & 1 \\
\hline $\begin{array}{l}\text { 37. "Nothing is free in this world". Do you agree with the phrase associated with } \\
\text { getting in return from the rental (see 36)? }\end{array}$ & 46 & 203 & 117 & 14 & 1 \\
\hline
\end{tabular}


The Preparation and Testing Of Instruments Research on Factors Affecting the Productivity of ..

\begin{tabular}{|c|c|c|c|c|c|c|}
\hline & $\begin{array}{l}\text { Each harvest is sold, you always set aside part of the proceeds from the business to } \\
\text { buy land or agricultural inputs. }\end{array}$ & 29 & 199 & 139 & 14 & 0 \\
\hline 39. & $\begin{array}{l}\text { I always motivate children to attend school up to higher education level, } \\
\text { notwithstanding I spend very big. }\end{array}$ & 104 & 219 & 43 & 15 & 0 \\
\hline 40. & How often do you anticipate saving for long-term needs & 41 & 179 & 147 & 14 & 0 \\
\hline 41. & $\begin{array}{l}\text { "Sacrifice to the smallest, to get the results as much as possible". Do you agree } \\
\text { with that sentence? }\end{array}$ & 70 & 118 & 116 & 75 & 2 \\
\hline 42. & $\begin{array}{l}\text { To obtain maximum results, you always work more than the normal amount of } \\
\text { working time ( } \geq 8 \text { Hours). }\end{array}$ & 22 & 167 & 174 & 18 & 0 \\
\hline 43. & $\begin{array}{l}\text { Does it worth, the results you get (the amount) as compared to the time and effort } \\
\text { you spend on it? }\end{array}$ & 55 & 203 & 115 & 8 & 0 \\
\hline 44. & How often do you get the results exceeded the normal amount & 23 & 105 & 220 & 33 & 0 \\
\hline 45. & You are always trying to gain huge profits in the business. & 50 & 182 & 128 & 21 & 0 \\
\hline 46. & $\begin{array}{l}\text { How often do you run a business with only underlies the courage regardless of the } \\
\text { risks that will occur (loss) }\end{array}$ & 51 & 71 & 156 & 103 & 0 \\
\hline 47. & $\begin{array}{l}\text { Do you agree that the goal of trying your household is to become rich beyond their } \\
\text { relatives, friends, neighbours, or anyone else who is equal to you? }\end{array}$ & 46 & 152 & 131 & 48 & 4 \\
\hline 48. & $\begin{array}{l}\text { How often do you compare household wealth holdings owned by relatives with } \\
\text { relatives, friends, neighbours, or relatives in the environment around the residence? }\end{array}$ & 21 & 51 & 100 & 167 & 42 \\
\hline \multicolumn{7}{|c|}{ Variable: Consumptive Behaviour (Y3) } \\
\hline & $\begin{array}{l}\text { How often do you draw up a family budget taking into account the level of } \\
\text { priority? }\end{array}$ & 90 & 137 & 126 & 28 & 0 \\
\hline 50. & $\begin{array}{l}\text { How do you budget appropriate interchanges with household income that you earn } \\
\text { (monthly period)? }\end{array}$ & 52 & 127 & 192 & 10 & 0 \\
\hline 51. & $\begin{array}{l}\text { As the head of the family, have you engaged by your wife in selecting the goods or } \\
\text { services to be consumed? }\end{array}$ & 54 & 133 & 156 & 38 & 0 \\
\hline 52. & $\begin{array}{l}\text { In fulfilling its range of goods and services required, you agree with the phrase: } \\
\text { "Better a little than nothing". }\end{array}$ & 122 & 178 & 64 & 17 & 0 \\
\hline 53. & How often do you buy the household products beyond basic needs? & 38 & 92 & 168 & 83 & 0 \\
\hline 54. & How often do you go to the market to buy household needs? & 35 & 105 & 174 & 67 & 0 \\
\hline 55. & How often does your family buy goods / services with a credit? & 30 & 28 & 211 & 109 & 3 \\
\hline & $\begin{array}{l}\text { In consuming every day, family provides only goods instantly done when } \\
\text { consumed. }\end{array}$ & 113 & 155 & 106 & 7 & 0 \\
\hline 57. & Family does not buy the goods / services because of the brand. & 95 & 160 & 122 & 4 & 0 \\
\hline & How often do you feel disappointed with the goods purchased? & 30 & 19 & 216 & 116 & 0 \\
\hline 59. & How often do you buy household goods without prior planning? & 30 & 42 & 195 & 113 & 1 \\
\hline 60. & Family always consume the goods due to the need and not because of cheap price. & 117 & 147 & 106 & 10 & 1 \\
\hline 61. & How often do you do not dispose of household items that are not consumed? & 59 & 143 & 162 & 16 & 1 \\
\hline 62. & $\begin{array}{l}\text { Pattern of consumption / lifestyles that exist in the environment and sisters, greatly } \\
\text { affect the activities of your household consumption. Do you agree with that } \\
\text { statement? }\end{array}$ & 63 & 118 & 131 & 69 & 0 \\
\hline & $\begin{array}{l}\text { How often does your household with the environmental buys luxury items such as } \\
\text { fancy furnishings, vehicles, jewellery, etc. }\end{array}$ & 32 & 56 & 173 & 115 & 5 \\
\hline \multicolumn{7}{|c|}{ Variable: Farmer's Household Productivity (Y4) } \\
\hline & $\begin{array}{l}\text { How successful, the land that you have used to make it meet household's } \\
\text { necessities? }\end{array}$ & 67 & 137 & 169 & 8 & 0 \\
\hline 65. & You always relentlessly utilize farm land for planting? & 61 & 212 & 92 & 16 & 0 \\
\hline 66. & You are always trying to work the land with your own labour? & 39 & 155 & 106 & 80 & 1 \\
\hline 67. & 4. How often do you spend working peasants in farming? & 27 & 98 & 108 & 106 & 42 \\
\hline 68. & How often do you utilize technology in farming? & 6 & 63 & 128 & 157 & 27 \\
\hline & How often do you use technology in farming? & 0 & 56 & 134 & 155 & 36 \\
\hline & You always managed to tuck doubles venture funds invested? & 21 & 70 & 150 & 130 & 10 \\
\hline 71. & How often do you mistakenly manage capital invested thus suffered a loss? & 1 & 7 & 124 & 192 & 57 \\
\hline
\end{tabular}

Source: processed

\section{Testing Research Instrument}

Data that have been collected through questionnaire, is now being tested in its validity and reliability. This test is meant to measure the valid and reliable questionnaire as a tool collecting data.

\section{Result of Instrument's Validity Test}

\begin{tabular}{|l|l|l|l|l|l|l|l|l|l|l|l|}
\hline Item & $\mathbf{r}$ & Sig & remarks & Item & r & Sig & remarks & Item & r & Sig & remarks \\
\hline 1 & 0.665 & 0.000 & Valid & 25 & 0.646 & 0.000 & Valid & 49 & 0.733 & 0.000 & Valid \\
\hline 2 & 0.621 & 0.000 & Valid & 26 & 0.782 & 0.000 & Valid & 50 & 0.773 & 0.000 & Valid \\
\hline 3 & 0.684 & 0.000 & Valid & 27 & 0.742 & 0.000 & Valid & 51 & 0.766 & 0.000 & Valid \\
\hline 4 & 0.676 & 0.000 & Valid & 28 & 0.707 & 0.000 & Valid & 52 & 0.669 & 0.000 & Valid \\
\hline 5 & 0.655 & 0.000 & Valid & 29 & 0.717 & 0.000 & Valid & 53 & 0.778 & 0.000 & Valid \\
\hline 6 & 0.623 & 0.000 & Valid & 30 & 0.738 & 0.000 & Valid & 54 & 0.740 & 0.000 & Valid \\
\hline 7 & 0.675 & 0.000 & Valid & 31 & 0.691 & 0.000 & Valid & 55 & 0.733 & 0.000 & Valid \\
\hline 8 & 0.688 & 0.000 & Valid & 32 & 0.723 & 0.000 & Valid & 56 & 0.546 & 0.000 & Valid \\
\hline 9 & 0.680 & 0.000 & Valid & 33 & 0.695 & 0.000 & Valid & 57 & 0.623 & 0.000 & Valid \\
\hline 10 & 0.663 & 0.000 & Valid & 34 & 0.497 & 0.000 & Valid & 58 & 0.715 & 0.000 & Valid \\
\hline
\end{tabular}


The Preparation and Testing Of Instruments Research on Factors Affecting the Productivity of ..

\begin{tabular}{|l|l|l|l|l|l|l|l|l|l|l|l|}
\hline 11 & 0.715 & 0.000 & Valid & 35 & 0.619 & 0.000 & Valid & 59 & 0.653 & 0.000 & Valid \\
\hline 12 & 0.725 & 0.000 & Valid & 36 & 0.635 & 0.000 & Valid & 60 & 0.692 & 0.000 & Valid \\
\hline 13 & 0.763 & 0.000 & Valid & 37 & 0.600 & 0.000 & Valid & 61 & 0.615 & 0.000 & Valid \\
\hline 14 & 0.676 & 0.000 & Valid & 38 & 0.638 & 0.000 & Valid & 62 & 0.769 & 0.000 & Valid \\
\hline 15 & 0.574 & 0.000 & Valid & 39 & 0.623 & 0.000 & Valid & 63 & 0.845 & 0.000 & Valid \\
\hline 16 & 0.647 & 0.000 & Valid & 40 & 0.614 & 0.000 & Valid & 64 & 0.476 & 0.000 & Valid \\
\hline 17 & 0.689 & 0.000 & Valid & 41 & 0.583 & 0.000 & Valid & 65 & 0.417 & 0.000 & Valid \\
\hline 18 & 0.720 & 0.000 & Valid & 42 & 0.591 & 0.000 & Valid & 66 & 0.452 & 0.000 & Valid \\
\hline 19 & 0.732 & 0.000 & Valid & 43 & 0.591 & 0.000 & Valid & 67 & 0.366 & 0.000 & Valid \\
\hline 20 & 0.726 & 0.000 & Valid & 44 & 0.601 & 0.000 & Valid & 68 & 0.507 & 0.000 & Valid \\
\hline 21 & 0.750 & 0.000 & Valid & 45 & 0.666 & 0.000 & Valid & 69 & 0.387 & 0.000 & Valid \\
\hline 22 & 0.732 & 0.000 & Valid & 46 & 0.580 & 0.000 & Valid & 70 & 0.396 & 0.000 & Valid \\
\hline 23 & 0.784 & 0.000 & Valid & 47 & 0.664 & 0.000 & Valid & 71 & 0.338 & 0.000 & Valid \\
\hline 24 & 0.710 & 0.000 & Valid & 48 & 0.649 & 0.000 & Valid & & & \\
\hline
\end{tabular}

Source: processed

Based on the results of testing the validity of the instrument variables farmer perception; conditions of farmers; farmer's attitude; productive behaviour; consumptive Behaviour; and productivity of farmer's households showed that all 71 items of the 35 indicators included in the questionnaire research is valid ( $\operatorname{Sig} \mathrm{t}>0.05)$, and therefore could be tested with the analysis that has been set.

\section{Result of Instrument's Reliability Test}

Results of testing the reliability of the instrument variables in this study are presented below:

\begin{tabular}{|c|c|c|c|c|c|c|c|}
\hline $\begin{array}{l}\text { Variable/ } \\
\text { Indicator }\end{array}$ & C. $\square$ & Cut off & & $\begin{array}{l}\text { Variable/ } \\
\text { Indicator }\end{array}$ & C. $\square$ & Cut off & \\
\hline \multicolumn{4}{|c|}{ Farmer's Perception $\left(X_{I}\right)$} & \multicolumn{4}{|c|}{ Productive Attitude $\left(\mathrm{Y}_{2}\right)$} \\
\hline $\mathrm{X}_{1.1}$ & 0.831 & 0.6 & Reliable & $Y_{2.1}$ & 0.772 & 0.6 & Reliable \\
\hline $\mathrm{X}_{1.2}$ & 0.762 & 0.6 & Reliable & $\mathbf{Y}_{2.2}$ & 0.794 & 0.6 & Reliable \\
\hline $\mathrm{X}_{1.3}$ & 0.897 & 0.6 & Reliable & $\mathbf{Y}_{2.3}$ & 0.745 & 0.6 & Reliable \\
\hline $\mathrm{X}_{1.4}$ & 0.823 & 0.6 & Reliable & $\mathbf{Y}_{2.4}$ & 0.801 & 0.6 & Reliable \\
\hline $\mathrm{X}_{1.5}$ & 0.770 & 0.6 & Reliable & $\mathbf{Y}_{2.5}$ & 1.000 & 0.6 & Reliable \\
\hline $\mathrm{X}_{1.6}$ & 0.820 & 0.6 & Reliable & $\mathbf{Y}_{2.6}$ & 0.783 & 0.6 & Reliable \\
\hline$X_{1.7}$ & 0.835 & 0.6 & Reliable & $\mathbf{Y}_{2.7}$ & 0.797 & 0.6 & Reliable \\
\hline $\mathrm{X}_{1.8}$ & 0.808 & 0.6 & Reliable & $\mathbf{Y}_{2.8}$ & 0.758 & 0.6 & Reliable \\
\hline \multicolumn{4}{|c|}{ Farmer's Condition $\left(X_{2}\right)$} & \multicolumn{4}{|c|}{ Consumptive Attitude $\left(Y_{3}\right)$} \\
\hline$X_{2.1}$ & 1.000 & 0.6 & Reliable & $\mathbf{Y}_{3.1}$ & 0.827 & 0.6 & Reliable \\
\hline $\mathrm{X}_{22}$ & 0.762 & 0.6 & Reliable & $\mathbf{Y}_{32.2}$ & 0.694 & 0.6 & Reliable \\
\hline $\mathrm{X}_{2.3}$ & 0.784 & 0.6 & Reliable & $\mathbf{Y}_{3.3}$ & 0.878 & 0.6 & Reliable \\
\hline $\mathrm{X}_{2.4}$ & 0.868 & 0.6 & Reliable & $\mathbf{Y}_{3.4}$ & 0.745 & 0.6 & Reliable \\
\hline$X_{2.5}$ & 0.780 & 0.6 & Reliable & $\mathbf{Y}_{3.5}$ & 0.884 & 0.6 & Reliable \\
\hline \multicolumn{4}{|c|}{ Farmer's Behaviour $\left(Y_{I}\right)$} & $\mathbf{Y}_{3.6}$ & 0.747 & 0.6 & Reliable \\
\hline $\mathrm{Y}_{1.1}$ & 0.769 & 0.6 & Reliable & $\mathbf{Y}_{3.7}$ & 0.852 & 0.6 & Reliable \\
\hline $\mathrm{Y}_{1.2}$ & 0.725 & 0.6 & Reliable & \multicolumn{4}{|c|}{ Farmer's Household Productivity $\left(Y_{4}\right)$} \\
\hline \multirow{4}{*}{\multicolumn{4}{|c|}{\begin{tabular}{l|l}
$Y_{1.3}$ & 0.739 \\
\end{tabular}}} & $\mathrm{Y}_{4.1}$ & 0.764 & 0.6 & Reliable \\
\hline & & & & $\mathrm{Y}_{4.2}$ & 0.840 & 0.6 & Reliable \\
\hline & & & & $\mathrm{Y}_{4.3}$ & 0.829 & 0.6 & Reliable \\
\hline & & & & $\mathrm{Y}_{4.4}$ & 0.745 & 0.6 & Reliable \\
\hline
\end{tabular}

Source: processed

Based on the results of reliability testing of instrument variables farmer perception; conditions of farmers; farmer's attitude; productive behaviour; consumptive Behaviour; and productivity of farm households showed that all 35 indicators of the six variables included in this study revealed reliable (Cronbach's alpha>0.6) or a reliable and suitable for use in subsequent data analysis.

\section{Results Description Instrument Research Variables}

Based on the results of the descriptive analysis of the research instrument, the mean values obtained (item, indicators and variables) are as follows: 1). For variable X1, the mean value of the items: 3.4 to 4.3 (Category strong to very strong), the mean value of the indicator: 3.44 to 4.13 (Category Strong), and the mean variable: 3.76 (Category Strong); 2). For X2, the mean value of the item: 3.41 to 4.12 (a strong category), the mean value of the indicator: 3.43 to 3.93 (Category Strong), and the mean variable: 3.8 (Category Strong); 3 ). For variable Y1, the mean value of the item: 3.13 to 4.12 (Category sufficiently strong to strong), the mean value of the indicator: 3.33 to 4.08 (Category sufficiently strong to strong), and the mean variable: 3.78 (Category Strong); 4). For variable Y2, the mean value of the item: 2.59 to 4.09 (Category weak to strong), the mean value of the indicator: 3.04 to 3.79 (Category sufficiently strong to strong), and the mean variable: 3,48 (Category Strong); 5). For variable Y3, the mean value of the items: 2.9 to 4.06 (Category sufficiently strong to 
The Preparation and Testing Of Instruments Research on Factors Affecting the Productivity of ..

strong), the mean value of the indicator: 2.93 to 3.94 (Category sufficiently strong to strong), and the mean variable: 3.5 (Category Strong); 6). For variable Y4, the mean value of the items: 2.2 to 3.83 (Category weak to strong), the mean value of the indicator: 2.56 to 3.76 (Category weak to strong), and the mean variable: 3.02 (Category sufficient strong). From the description of this instrument, it can be stated that deserves to be taken into consideration in testing the validity and reliability of the construct appropriate inferential analysis.

\section{The Results of Testing Validity and Reliability Construct \\ 1. Testing of Construct Validity \\ a. Convergent Validity $1^{\text {st }}$ Order (Item)}

Convergent Validity $1^{\text {st }}$ order is intended to determine whether the item in question is valid in measuring indicators. Convergent validity 1 st order every item in measuring the indicators shown by the size of the loading factor. An item is said to be valid when the loading factor item is positive and greater than 0.5.

Based on test results Convergent Validity 1st order, the overall value of items declared invalid by loading factor $>0.5$. For variable X1 with 16 items, loading factor is positive and greater than $0.5(0.745$ to 0.922); For variable $\mathrm{X} 2$ with 9 items, loading factor is positive and greater than 0.5 (0.652 to 0.923); For variable Y1 with 6 items, loading factor is positive and greater than 0.5 (0.716 to 0.849); For variable Y2 with 17 items, loading factor is positive and greater than $0.5(0,844$ to 0,929$)$; For variable Y3 with 15 items, loading factor is positive and greater than 0.5 (0.712 to 0.925$)$; For variable Y4 with 8 items, loading factor is positive and greater than 0.5 (.680 to .978). Based on test results Convergent Validity 1st order can be seen that all items generating loading factor greater than 0.5. Thus these items can be declared valid or capable of measuring the indicators corresponding to the item.

\section{b. Convergent Validity Indicator $2^{\text {nd }}$ Order (Indicator)}

Convergent Validity $2^{\text {nd }}$ order is intended to determine whether or not a valid indicator to measure latent variables. Convergent validity 2 nd order every indicator in measuring the latent variable indicated by the size of the loading factor. An indicator is said to be valid when the loading factor of the indicator is positive and greater 0.5. Based on test results Convergent Validity 2nd order, the overall indicator is valid with a value of loading factor> 0.5 , namely: 1). For variable X1 with 8 indicators, loading factor is positive and greater than 0.5 (0.627 to 0.887$) ; 2)$. For variable $\mathrm{X} 2$ with 5 indicators, loading factor is positive and greater than 0.5 (0.627 to 0.887); 3). For variable Y1 with 3 indicators, loading factor is positive and greater than 0.5 (0.728 to 0.833$) ; 4)$. For variable Y2 with 8 indicators, loading factor is positive and greater than 0.5 (0.607 to 0.843$)$; 5). For variable Y3 with 7 indicators, loading factor is positive and greater than 0.5 (0.577 to 0.981$)$; 6). For variable Y4 with 4 indicators, loading factor is positive and greater than 0.5 (0.709 to 0.797). Based on the results of the 2nd order analysis measurement model can be seen that all the indicators / constructs each produce a latent variable loading factor> 0.5 . Thus, the indicator can be declared invalid or be able to measure latent variables corresponding to the indicator.

\section{c. Discriminant Validity}

Discriminant validity of each variable in measuring the latent variable indicated by the roots of Average Variance Extracted (AVE). A variable is said to have discriminant validity if the root of AVE> correlation between latent constructs (Fornell and Larcker, 1981).

Based on the results of the discriminant validity of each latent variable indicates AVE values> 0.5. Learn as follows: 1). For variable X1, AVE value has a value between 0.785 to 0.902 , so it can be stated that the root of the AVE-value> the correlation between latent constructs; 2). For X2, AVE value has a value between 0.794 to 1.000 , so it can be stated that the root of the AVE-value> correlation between latent constructs, and the tendency of unique value; 3). For variable Y1, AVE value has a value between 0.765 to 0.793 , so it can be stated that the root of the AVE-value> the correlation between latent constructs; 4). For variable Y2, AVE value has a value between 0.551 to 0.833 , so it can be stated that the root of the AVE-value> the correlation between latent constructs; 5). For variable Y3, AVE value has a value between 0.723 to 0.892 , so it can be stated that the root of the AVE-value> the correlation between latent constructs; 6). For variable Y4, AVE value has a value between 0.781 to 0.855 , so it can be stated that the root of the AVE-value> correlation between latent constructs. From the above test results, it can be concluded that the root of the Average Variance Extracted (AVE) of all constructs 6th latent variables are greater than the correlation coefficient of latent constructs. This means, discriminant validity, all the indicators that measure the latent variables have been met, and it can be stated that the whole item is valid and able to measure the indicators corresponding to these items.

\section{Testing of Construct Reliability}

Construct reliability testing conducted using measures of reliability construct or use the item number of the overall variance explained by latent constructs or so-called discriminant reliability. Criteria for testing if the 
value of composite reliability (CR) or greater reliability rho 0.7 (Cut off) it can be stated constructs have been reliable.

Based on the results of testing the reliability of the construct, the value of composite reliability of each construct from all six latent variables, as follows: 1). For variable $\mathrm{X} 1$, has a composite reliability values $>0.7$ with CR values of all 8 indicators between 0.76 to $0.90 ; 2$ ). For X2, has a composite reliability values $>0.7$ with $\mathrm{CR}$ values of all five indicators of between 0.77 to $1.00 ; 3$ ). For variable Y1, has a composite reliability values> 0.7 with $\mathrm{CR}$ values from all three indicators between 0.74 to 0.77 ; 4). For variable Y2, has a composite reliability values $>0.7$ with $\mathrm{CR}$ values of all 8 indicators between 0.74 to $1.00 ; 5)$. For variable $\mathrm{Y} 3$, has a composite reliability values $>0.7$ with $\mathrm{CR}$ values of all seven indicators of between 0.70 to $0.89 ; 6$ ). For variable $\mathrm{Y} 4$, has a composite reliability values> 0.7 with $\mathrm{CR}$ values from all four indicators of between 0.76 to 0.85 . From the above test results, it can be concluded that the value of composite reliability (CR) of the total latent constructs of greater than 0.7 (Cut off) it can be stated constructs have been reliable.

\section{Conclusion}

Based on the results of research and discussion in the previous chapters, with reference to the purpose of this study, summarized some of the following:

- Characteristics of household's farmers in Minahasa has attractive value. This is illustrated by the heterogeneity of the data/results, which are based on age, education, land ownership, number of dependents, farm income, farm earnings beyond, and additional work.

- Development (preparation and testing) research instruments have relevance to the existence of household's farmers. This is illustrated by the perception of the average value of households that are in the strong category on the research instrument. And the Likert scale used in this study are considered suitable instruments as an alternative to argue about the productivity of household's farmers.

- The results of testing validity and reliability instrument with the test of sig.t (valid) and Cronbach's alpha (reliable) indicate validity (sig.t <0.05) and reliability (Cronbach's alpha > 0.6) instrument. It can be concluded that all the instruments of research validity/accuracy and reliability/suitability in measuring the productivity of household's farmers in Minahasa district.

- The test results showed that the construct validity convergent validity, 1 st and 2 nd has a value of loading factor $>0.05$ and discriminant validity have root value of AVE > correlation between latent constructs. It can be concluded that the examination of the item and the indicator/manifest of latent constructs are valid and fulfilled. And to construct reliability testing, found that the value of composite reliability (CR) of the total latent constructs of greater than 0.7 (Cut off) it can be stated constructs have been reliable. This confirms that the instrument of the 6th latent constructs have been eligible for further analysis.

\section{Recommendation}

Based on research findings about the preparation and testing of the instrument on the factors that influence the productivity of household's farmers in Minnehaha, researchers recommend further research to be able to use these results as a reference for both the reference and the process of analysing. Furthermore, the results of this study can be used as a reference for the development of the instrument.

\section{Literature}

[1]. Barnum, H.N. and L. Squire. 1978. An Econometric Application of the Theory of the Farm-Household. Journal of Development Economics, (6): 79-102.

[2]. Campbell, D. and Fiske. D. (1959). "Convergent and Discriminant Validation", Psychological. Bulletin, Vol. 56, h. 81 -1 05

[3]. Daniel, W.W, and Terrel, J.C. (1989). Business Statistics Fifth Edition, Boston: Houghton Mifflin Company.

[4]. Djaali dan Pudji Muljono. 2008. Measurements in the Field of Education. Jakarta: Grasindo

[5]. Fornell, C and Larcker, D.F. (1981). Evaluating structural equation models with unobservable variables and measurement error. Journal of Marketing Research, 18 (1), 39-50)

[6]. Krech, D. C., R. S. Ballacey, and Egerton L. 1963. Individual in Society. New York: Mc Graw Hill Co.

[7]. Mueller, Daniel J. 1986. Measuring Social Attitudes. New York: and London: Teacher College, Columbia University

[8]. Notoatmojo, S, 2007. Health Promotion and Behavioural Sciences. Rineka Cipta. Jakarta.

[9]. Sarwono. S. W. 2002. Individual Social Psychology and Social Psychology Theory. Balai Pustaka. Jakarta

[10]. Sawit, M.H, 1994. Food Demand Analysis: Empirical Evidence Theory of Household Agriculture. Economics and Finance Indonesia Volume XLII, No. 1. 1994.

[11]. Sevilla, C.G (1988), language expert Alimudin Tuwu (1993), Introduction to Research Methods, Jakarta: UI Press

[12]. Singh, I.J, et.al. 1986. Agricultural Household Models: Extensions, Applications, and Policy. Published for The World Bank. The John Hopkins University Press, Baltimore

[13]. Sinungan, M. 2003. Productivity What and How. Jakarta: Bumi Aksara

[14]. Soebiyanto, FX. 1999. Farmer participation in counselling to increase farm productivity Rice (the case in the district of Klaten in Central Java) - Thesis of Postgraduate - IPB Bogor.

[15]. Sugiyono, (2010). Research Method Quantitative Qualitative and R \&. Bandung: Alfabeta.

[16]. Suryabrata, S, (2008). Research methodology. Jakarta: Raja Grafindo Persada. 2008

[17]. Thorndike, Robert L. 1982. Applied Psychometrics. Boston: Houghton Mifflin Company 